\title{
Media Education and the New Evangelization Part One: Media Components and Challenges ${ }^{1}$
}

\author{
MIROSŁAW CHMIELEWSKI \\ The John Paul II Catholic University of Lublin \\ chmiel@kul.pl, ORCID: 0000-0002-6903-479X
}

\begin{abstract}
This article represents the first instalment of a two-part study on the relationship between media education and the new evangelization. The author puts forward a claim that pursuing the new evangelization in the Church demands the media education of the evangelizers and their cooperation with leaders in media education. Proving this thesis advances via three stages: (1) Outlining selected components of the media context of the new evangelization, in light of selected theses from the Church Magisterium; (2) Discussing selected challenges for both media education and the new evangelization; and (3) Presenting selected postulates and educational proposals for media literacy formation and the new evangelization. This last part outlines five media components of the new evangelization, along with three main challenges for both media and the new evangelization, stemming from their interrelationship. The main research methods used in this article are: the Magisterial method, sub ratione Dei, and comparative synthesis.
\end{abstract}

Keywords: Media education, new evangelization, internet, social media, theology of media

\begin{abstract}
"In the Christian tradition, religion is based on the concept of 'community' and worship requires a coming together of common believers. In an increasingly individualized and computerized society, how will the Church continue its task of sharing the good news and serving others?"
\end{abstract}

(E. Thoman 1977) $)^{2}$

In recent years, the debates of the general Synods of Bishops, i.e. the meeting of bishops of the Catholic Church, have received wide media coverage. Both the two-stage Synod on the Family (2014-2015) and the recent, special Synod for the Pan-Amazon region in 2019 were reported by the media. It is however noteworthy that the media created their own image of the Synods. All sorts of media representations were created by individuals, interest circles or media companies. Simple observation without advanced research tools suffices to exhibit that there were - as if - two synods: the

1 The project is funded by the Minister of Science and Higher Education within the program under the name "Regional Initiative of Excellence" in 2019-2022, project number: 028/RID/2018/19, the amount of funding: 11742500 PLN.

2 Thoman, "I Hate it, but I Love it." 
real one and the "media synod." Also, after the episcopal meeting dedicated to the Amazon, the media messages depicted many versions of the post-synodal document that were attributed to Pope Francis. And when Pope Francis ultimately issued his "non-media" exhortation, some journalists expressed disappointment.

The synod events described above, being part of the current evangelization processes of the Catholic Church, unveil an obvious need of media competences. These competences are necessary, on the one hand, for the proper "reading" of media messages. On the other hand, having the competences equals having evangelization skills in a world in which every sphere of life, including religious, is media dependent. This involvement of the media not only in reporting, but also in active co-creation of events that are crucial for the shape of the new evangelization in the Catholic Church inevitably leads to many questions. It is therefore necessary to diagnose the level of knowledge about the nature and functioning of the means of social communication, the level of knowledge about media culture, the level of media literacy of the Christian community members, and above all, of those responsible at various levels (lay and clergy) for the evangelization mission of the Church. A claim seems justified that without media education it is virtually impossible to carry out the works of the new evangelization responsibly, effectively and fruitfully. The insights into the contemporary Magisterium of the Catholic Church provide sufficient grounds to support the interdependence of the new evangelization with the ecclesial teaching about the media. Therefore, the intention of the author of this article is to highlight an urgent need for media education as part of the research and practice in the field of pastoral theology and in evangelization-oriented pastoral care. The aim of the article is to attempt to answer the question about the nature of the relationship between media education and the new evangelization in the Catholic Church and to explore the pastoral and educational consequences for those responsible for the new evangelization and media literacy formation.

The process of answering the above questions will take place in three stages. At the first stage, selected components of the medial context of the new evangelization will be presented in the light of selected official statements in the teaching of the Church. The second stage will be an attempt to show selected aspects of the nature of the relationship between media education and the new evangelization, as well as its consequences for both research and practice of the new evangelization. At the third, final stage, pastoral postulates and educational proposals will be formulated for media literacy formation in evangelisation-oriented pastoral care. For editorial reasons, this comprehensive scientific reflection on the issues at hand is disseminated in two separate articles. This first article deals with the first two stages outlined above, while the second article will deal with the third stage of our reflective explorations.

The term media education, as used in this publication, is understood as education to use media, which means developing relevant competences in the field of 
media and information ${ }^{3}$. Whereas, the term "new evangelization" is used as taken directly from the documents of the contemporary teaching of the Catholic Church. Thus, it is understood here as a direct, living sharing of the Gospel of salvation in Jesus Christ, based on the witness of faith, bearing in mind the specific pastoral situation of the recipients of the message of faith (See $E G, 14$ ).

The sources on which this text is based is the teaching of the Church, especially in the field of media research and the new evangelization as well as the relevant literature of the subject. The research process employs selected methods and techniques used within the analytical paradigm in pastoral theology, including the magisterial method, the sub ratione Dei method of interpretation, critical analysis and the comparative synthetic method.

\section{Selected Components of the Medial Context of the New Evangelisation}

In contemporary times, markedly since John Paul II's remarks and appeals (especially since 1988 and the exhortation Christifideles laici), the issue of the new evangelization has been introduced to the ecclesial debate. The debate, with varying degrees of intensity, had lasted for many years until it reached a kind of peak and a new opening at the XIII General Synod of the Bishops in Rome in $2012^{4}$. The main motif of the meeting was The New Evangelization for the transmission of the Christian faith. The Synodal documents, as well as the two pre-synodal ones, Lineamenta (2011) and Instrumentum Laboris (2012), outline the contemporary factors influencing the new evangelization. One of them is means of social communication, and more broadly media culture, especially as created with digital technologies. Thus, the Synod confirms the reflection already present in the teaching of the Church that it is necessary for the Church's contemporary missionary ministry to be aware of the potential of the modern media. At the same time, the Church recognizes multiple challenges and threats posed the media revolution. Following the inspiration of the 2012 Synod on the new evangelization, this section of the article discusses a selection of the essential components of the medial context of the new evangelization and their analysis in the light of the contemporary media doctrine of the Church.

3 See: Drzewiecki, Edukacja medialna, 27-30; See: Fedorov, Media and Information, 17; See: Chmielewski, "Edukacja medialna," 12-13; In the post-conciliar teaching of the Church on the media, one of the leading areas is media literacy and education. They are synonymous with such terms as: media education and media literacy formation. Both terms are present in the Church's documents, although the latter more accurately reflects the nature of Christian education and Christian formation in the Church also in the context of contemporary media.

4 See: Wielebski, "Istota i sposoby realizacji," 65-71. 
The first component of the medial context of the new evangelization that appears in the thematically focused analysis of the Church's teaching on the media is the Church's openness to the media world. This attitude of the Church was confirmed in the Vatican II Decree on the means of social communication Inter mirifica (1963) and has been constantly developing. Despite the many challenges and occasional, but serious threats posed by the media, the Church continues to see them as great works of the human mind. This is evidenced by the fact that the means of social communication are understood as one of today's "signs of the times," which must be carefully interpreted in order to carry out faithfully the salvific mission of Christ in the Church. This way of conceiving the role of the media can be exemplified by Pope Francis' ideas expressed in 2014: "the revolution taking place in communications media and in information technologies represents a great and thrilling challenge; may we respond to that challenge with fresh energy and imagination as we seek to share with others the beauty of God." ${ }^{5}$

The second component that expresses the Church's attitude towards the means of social communication is treating them as an instrument, a tool for evangelization. This marks a technological approach to the mass media, which opens the Church to the opportunity of instantaneous, wide and - with the rise of the Internet - intercommunicative transmission of faith. This way of perceiving the media is emphasized by the fact that the Church established a world day of prayer for the media (in 1967), later referred to as the World Day of Social Communications (or World Communications Day). The term "means," (in Italian: strumenti di comunicazione sociale) as found in the concept of "means of social communication," implies instruments of contemporary social communication. This way of conceptualizing the media and their role in evangelization is confirmed by many statements in the Magisterium of the Church. As an example, one can pinpoint the famous words of Pope Paul VI from the Apostolic Exhortation Evangelii nuntiandi, which are constantly re-quoted in many other official documents. One such re-quote comes from the Fifth General Conference of the Bishops of Latin America and the Caribbean - Aparecida, 13-31 May 2007. The Aparecida document is permeated with the message of the new proclamation of the Gospel. It defines the Internet as an advantageous set of tools for the new evangelization:

"Our century is characterized by the mass media or means of social communication, and the first proclamation, catechesis or the further deepening of faith cannot do without these means". When they are put at the service of the Gospel, they are capable of increasing almost indefinitely the area in which the Word of God is heard; they enable the Good News to reach millions of people. The Church would feel guilty before the Lord if she did not utilize these powerful means that human skill is daily rendering more perfect. It is through

5 Francis, WDSC 48. 
them that she proclaims "from the housetops" (cf. Mt 10:27; Lk 12:3) the message of which she is the depositary. In them she finds a modern and effective version of the pulpit. Thanks to them she succeeds in speaking to the multitudes (485; also see: $362 ; 488-490)^{6}$.

Evangelization, i.e. communication of faith in and through the media, cannot be limited only to the instrumental level, treating media messages solely as carriers of cultural and religious content. This is all the more important because such a point of view seems to dominate in the pastoral, catechetical and preaching practice of the Church. However, the instrumental view of the media is apparently insufficient. The Church is aware of this and perceives the means of social communication in cultural contexts. Media culture is the third component of the discussed context of the new evangelization. John Paul II focused on it in Redemptoris Missio, his encyclical dedicated to evangelization and the Church's mission in the contemporary world. $\mathrm{He}$ wrote about new cultural sectors as modern evangelization equivalents of the Areopagus:

The first Areopagus of the modern age is the world of communications, which is unifying humanity and turning it into what is known as a "global village." The means of social communication have become so important as to be for many the chief means of information and education, of guidance and inspiration in their behavior as individuals, families and within society at large. [...] Involvement in the mass media, however, is not meant merely to strengthen the preaching of the Gospel. There is a deeper reality involved here: since the very evangelization of modern culture depends to a great extent on the influence of the media, it is not enough to use the media simply to spread the Christian message and the Church's authentic teaching. It is also necessary to integrate that message into the "new culture" created by modern communications. This is a complex issue, since the "new culture" originates not just from whatever content is eventually expressed, but from the very fact that there exist new ways of communicating, with new languages, new techniques and a new psychology $(R M, 37 \mathrm{c})$.

The idea expounded in the quote above has been repeatedly taken up by John Paul II in his messages, especially in the context of contemporary culture ${ }^{7}$. This current of theological-cultural reflection on the media, especially on new media (Internet, social media) in the context of evangelization was further developed by Pope Benedict XVI. In the thought of the pope emeritus, the new media culture, with its remarkable dynamics within the confines of the "digital continent," constitutes a challenge for the contemporary Church. In his opinion, there is an analogy between the evangelization circumstances of the contemporary Church and the ancient

Aparecida, 235.

See: Kawecki, Kościót i kultura, 181-269. 
times, when Christianity entered into a dialogue with the then culture of the Greek and Roman communities. It seems reasonable to claim that a key text on media culture in Benedict XIV rich legacy is his concluding message for World Day of Social Communications 2009:

I would like to conclude this message by addressing myself, in particular, to young Catholic believers: to encourage them to bring the witness of their faith to the digital world. Dear Brothers and Sisters, I ask you to introduce into the culture of this new environment of communications and information technology the values on which you have built your lives. In the early life of the Church, the great Apostles and their disciples brought the Good News of Jesus to the Greek and Roman world. ${ }^{8}$

The pope, referring to the origins of the Church, recalled the fact that evangelization has borne fruit by learning about the culture of the Greco-Roman world'. The Church had to face a new "world" for Her then, incorporating the Gospel into its cultural framework. In this way, She introduced persons and peoples to communication and experience of faith. By analogy, as the pope emeritus observes, "also today, the proclamation of Christ in the world of new technologies requires a profound knowledge of this world if the technologies are to serve our mission adequately ${ }^{10}$." Thus, referring to the Church's ancient practice, Benedict XIV pointed out that also today the preachers of the Gospel were facing the task of entering a new, digital world. A special role in this respect falls to the young, so-called "digital generation," which can effectively introduce the "emigrants" to the experience of the digital world, inheriting the experience of faith from these older generations ${ }^{11}$.

The fourth component that is present in the contemporary teaching of the Church on the medial context of evangelization is an urgent need for visual communication in the transmission of faith. Therefore, there emerges a need to develop visual competences of those personally responsible for the proclamation of the Gospel. Doctrinal inspirations for the characterization of this component can be found in the extremely bountiful text of the 2013 encyclical Lumen fidei by Pope Francis. The author emphasizes the ancient roots of visuality in the communication of faith. The biblical roots of visual communication can be found in the writings of the New Testament, especially those by St. John the Apostle and Evangelist. Pope Francis' encyclical explains that two ways of knowing in faith -fides ex auditu and fides ex visu - are not self-contradictory because the biblical teaching rests on these complementary channels: "The Old Testament combined both kinds of knowledge,

\footnotetext{
Benedict XVI, WDSC 43.

See: Celli, "Ewangelizacja i nowe techniki."

Benedict XVI, WDSC 43.

See: Chmielewski, "Kultura medialna," 166-167.
} 
since hearing God's word is accompanied by the desire to see his face. The ground was thus laid for a dialogue with Hellenistic culture, a dialogue present at the heart of sacred Scripture" $(L F, 29)$. Therefore, the pictorial turn (W. J. T. Mitchell) and the growing domination of audio-visual media - with the strong accent on the visual communication - do not come as a surprise in the practice of preaching the Word of God in the Church. Nevertheless, the image-dominated contemporary culture exhibits a strong tension between the spheres of logos and visus, where the latter seems to dominate noticeably over the spoken word ${ }^{12}$. This problematic interrelation strongly resounds in the words of Pope Francis, in the context of the evangelization of the youth: "an approach to reality that privileges images over listening and reading has influenced the way people learn and the development of their critical sense" $(\mathrm{ChV}, 86)$.

The visual dimension of the medial context of the new evangelization stands out perfectly clear in two catechetical documents that demarcate the evangelization trend in the Church. The first one, which is the voice of the Church's Magisterium, is the Compendium of the Catechism of the Catholic Church (2005). In his Introduction to the document, Benedict XVI explains that the images included, taken from the rich legacy of religious art, constitute one of the three defining features of the volume. Acknowledging the visuality of contemporary culture, the pope emeritus stresses that image is a highly effective means of "evangelical preaching" and it can express "much more than the word itself." ${ }^{13}$ Visual communication in its various forms is not only an illustration of the content conveyed verbally, but in the transmission of faith it is equivalent to the word. This is exactly why Christian iconography is a kind of mystagogy in the experience of the transcendent message of the Gospel and of the greatest mysteries of the Christian faith ${ }^{14}$.

The second catechetical document to be mentioned is Youcat. Youth Catechism of the Catholic Church, which was born as a bottom-up pastoral initiative in a local Church community. Because of its addressees and its form, it has become so relevant to the contemporary Church that it was turned into a catechism for the universal Church. The visual elements present in Youcat are not just a simple illustration of the written code, but have a catechetical and didactic meaning on their own. They show that the response of faith from Scripture and the teachings of the Church corresponds to different circumstances of life and that there are no spheres of human life excluded from the power of God's grace ${ }^{15}$.

The fifth component of the medial context of the new evangelization is participation in the digital world. The digital reality of the new media is a merger of real-life

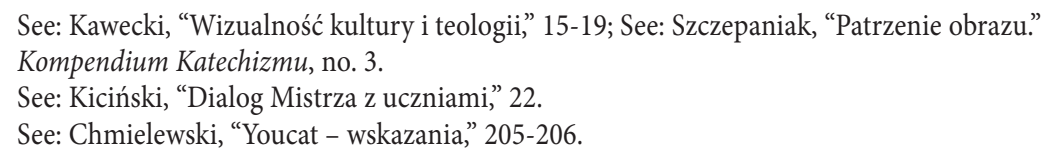


and virtual space. This space engages people, who remain in permanent mediated intercommunication with the others. Social media are both an opportunity and a challenge for the Church in Her aspirations to preach the Gospel to the modern world fruitfully through diverse pastoral activities. Pope Benedict XVI repeatedly pointed out that the "digital continent" is the new Areopagus of evangelization. He encouraged and urged pastoral activities that would engage the evangelizers in this space. His appeal was addressed to all those undertaking the new evangelization, priests in particular. In his Message for the 44th World Day of Social Communications, the pope emeritus indicated a need for the priests to be actively present in the digital world, serving as animators to all active participants, undertaking dialogue and pursuing their own priestly formation - both theological and medial:

Yet priests can rightly be expected to be present in the world of digital communications as faithful witnesses to the Gospel, exercising their proper role as leaders of communities which increasingly express themselves with the different "voices" provided by the digital marketplace. Priests are thus challenged to proclaim the Gospel by employing the latest generation of audiovisual resources (images, videos, animated features, blogs, websites) which, alongside traditional means, can open up broad new vistas for dialogue, evangelization and catechesis ${ }^{16}$.

What is more, Pope Francis encouraged priests to enter the world of new media and settle there: "Let us boldly become citizens of the digital world. The Church needs to be concerned for, and present in, the world of communication, in order to dialogue with people today and to help them encounter Christ. She needs to be a Church at the side of others, capable of accompanying everyone along the way"17. A need for an evangelizing presence in the digital world is reaffirmed by the fact that for the digital generation, as an audience of the evangelizing message, the presence and communication in the digital space is as real as the physical space direct communication is for the older generation - a fact which is also brought to mind by Benedict XVI:

Believers are increasingly aware that, unless the Good News is made known also in the digital world, it may be absent in the experience of many people for whom this existential space is important. The digital environment is not a parallel or purely virtual world, but is part of the daily experience of many people, especially the young. Social networks are the result of human interaction, but for their part they also reshape the dynamics of communication which builds relationships: a considered understanding of this environment is therefore the prerequisite for a significant presence there ${ }^{18}$.

16 Benedict XVI, WDSC 44.

17 Francis, WDSC 48.

18 Benedict XVI, WDSC 47. 
The digital world as analysed in this text, that is as a component of contemporary evangelization efforts, was particularly actively engaged in the process of preparation and conduct of the special general Synod on youth in the Church. The synodal intention to speak directly to the youth was manifest through several events. The first was an online questionnaire, available for six months (June - December 2017) in different languages. According to the Vatican, 200 thousand young people approached the questionnaire, with $50 \%$ of the respondents (100 thousand) completing fully ${ }^{19}$. Also, the three hundred young auditors of the Synod present in Rome were accompanied by fifteen thousand virtual participants through social media. For a week, they were actively involved in the Synod through an exchange of views and written reflections, submitted to the Synod's fathers ${ }^{20}$. The post-synodal apostolic exhortation by Pope Francis "Christus vivit" points to three key "synodal nodes." These can be defined as three current paradigms of pastoral work and of the active presence of young people in the Church. One of these is "digital environment" (ChV, 86-90). From the text of the exhortation there emerges, on the one hand, a vast spectrum of opportunities offered by digital media in the fields of communication, education and community interaction. On the other hand, the functioning in the digital media environment is a serious challenge for the new evangelization, because when on the Web, a modern human being can be exposed with a wide range of manipulation practices, violence, pornography and other threats. It seems that between these antipodes of the digital world, media education arises as a necessity. It constitutes an expression of the Church's concern for the development of youth and the growth of their faith, on the one hand, being a preventive and curative action, on the other.

\section{Media Education as Indispensable for the New Evangelization: Challenges}

The nature of the interrelation between media education and the new evangelization can be described with a paraphrase of one of the main truths of faith. The above formulation is highly inspiring, given that evangelization is transmission of the Christian message and a communication of living the Gospel, which is to lead to a personal act of faith in Jesus Christ. The interrelation between media education and the new evangelization obtains in multiple dimensions. The interrelation can be mutually inspiring, sometimes conditioning the form, methods and content of media education. It can also hqelp in better understanding the addressees of evangelization, because of their media immersion. The next section will present selected

\footnotetext{
19 General Secretariat, The World of New Generations.

20 General Secretariat, Final Document; also see: Beaton, "Between the Center and the Margins."
} 
challenges that arise from the relationship under analysis, which mutually reinforce, profile, give new shapes and set new directions for both media education and the new evangelization.

\section{a. Media Education of the Evangelizers}

John Paul II's idea that "the faith that does not become culture is a faith that is not fully received, not entirely thought through, not faithfully lived" seems to be a kind of paradigm for the contemporary understanding of the new evangelization in the medial context. As noted above, media culture is the modern Areopagus for the new evangelization. A necessary precondition for evangelization to enter into a dialogue with contemporary culture is understanding this culture, which presupposes an understanding of the media ("understanding media is integral to understanding culture") ${ }^{21}$. Therefore, contemporary evangelizers should be equipped with cultural and media competence. This is why theology of the media takes up a dialogue with contemporary culture and makes a proposal for media education, extended to theological and ecclesial contexts, which is defined as media literacy formation. It constitutes is a subject matter that concerns the Church as a whole. The above-mentioned Aparecida document on the New Evangelization clearly emphasizes the thought contained in many other messages of the Church on the necessity to form "disciples and missionaries" in the filed of social communications, obliging the bishops to "accompany those devoted to communications" (no. 486). The document specifies what this accompaniment means by posing nine objectives in this respect. What links all these nine objectives is care for media education. The major aim of media literacy formation, according to the document, is to create a "new culture of communication" (cf. No. $486 \mathrm{a}-\mathrm{i} ; 488-490$ ). This is all the more significant in view of the fact that this term appears as one of the key concepts in Pope Francis' media doctrine. There is a sufficient number of similar statements made by the Magisterium Ecclesiae to argue that, from the theoretical point of view, the Church acknowledges a need for media literacy in the religious-cultural context. Nonetheless, the formative practice and the pastoral care in and through the media is insufficient, as evidenced by the research carried out in Poland. The insufficiency in question is caused, among other things, by the lacking competences of those responsible for evangelization ${ }^{22}$.

Equally reasonable is to pose new questions and claims for further research verification of the causes for this state of affairs. It can be that one such cause is a lack of belief in the meaningfulness of media education. This is because evangelization media presence is often perceived in terms of hard and demanding struggle, apologetic discourse and a thorny dialogue with contemporary postmodern culture. Or is

21 Iaquinto - Keeler, "Faith-Based Media," 14.

22 See works: Szajda, Kompetencje medialne; Kasowski, Edukacja medialna. 
it that the Church gives up the area of a troublesome dispute and doubts the sense of organic evangelization work, "going back the basics?" In many pastoral activities, the pastoral care of evangelization seems to exhaust itself in evangelization "flash" messages, events and religious shows with charismatic evangelizers. Undoubtedly, such events are needed, but they cannot constitute a programme for the new evangelization. Are we not too enthusiastic - as the Church community - about a style of media narrative that promotes the emotional dimension of communication above all the others? Indeed, there obtains a relationship fides et emotio, but the act of faith is a rational act. Faith received in the heart leads to religious transformation, but proclaiming it with the mouth presupposes a rational act of comprehension. Therefore, for "pastoral metanoia" to take place, the Church needs to open Her doors, institutions and structures to media literacy formation. Without that step, we will fail to understand the media, and consequently, we will not be able to communicate with contemporary culture. Thus, we will fail to reach the addressees of the Gospel's message, especially those representing the media generation " $Z$."

\section{b. Social Commitment}

The social teaching of the Church is an integral part of the preaching of the Gospel. It calls for social commitment, being a leaven of change in this sphere. This very dimension of evangelization was recalled by Benedict XVI in his encyclical Caritas in veritate. We can read there that:

Between evangelization and human advancement - development and liberation - there are
in fact profound links: on the basis of this insight, Paul VI clearly presented the relation-
ship between the proclamation of Christ and the advancement of the individual in society.
Testimony to Christ's charity, through works of justice, peace and development, is part and
parcel of evangelization, because Jesus Christ, who loves us, is concerned with the whole
person. These important teachings form the basis for the missionary aspect of the Church's
social doctrine, which is an essential element of evangelization. The Church's social doc-
trine proclaims and bears witness to faith. It is an instrument and an indispensable setting
for formation in faith $(C V, 15)$.

Thus, the Christian message conveyed in the process of evangelization contains guidance to inspire Christians to undertake activity in the social space. One of these activities is social communications. Media education is indispensable to engage creatively and effectively in the reception and construction of this dimension of life in post-industrial societies, which are also defined with the use of such concepts as the information society, knowledge society, network society or communication society. From the perspective of the new evangelization, media education, both at the stage of theory and practice, represent something more than just a branch of education activ- 
ity. It is a process of equipping the agents of both education and evangelization with social skills and competences. In other words, education for the reception of media serves evangelization in that it enables introducing into social life the principles worked out by the Church: solidarity, common good and subsidiarity. As G. Łęcicki points out, "media education thus appears to be an important need of modern society, with its qualities of communicative democracy, based on education in critical, selective and active reception of media messages, in order to recognize their real content and ideological message, containing a specific vision of the world and of the human being." ${ }^{23}$ Thus, media literacy is one of the empowering factors in constructing a modern society. As leaders of the Methodist Church in the USA stress, being citizens of particular national communities, Christians cannot participate in social and political life in a fully responsible way without extensive use of broadly understood media. Contemporary expansion of the media world and media-dependence of all spheres of human life poses serious threats. One of them is a risk of reducing the human being to the position of an ignorant consumer of media-generated content. Another is that media content can be reduced to merchandise, sold to masses by large media outlets: "created and controlled by a relatively small number of powerful international media corporations." ${ }^{24}$ As noted by G. Ptaszek, a social challenge in the age of algorithmization and Big Data is to develop an ability to manage one's privacy, i.e. an ability to protect oneself from online data tracking. In other words, this means educational efforts to awaken awareness of the algorithmization behind the social communication processes and to inspire critical thinking as a tool of exposing online disinformation ${ }^{25}$.

The social dimension is a point of convergence of media education and the new evangelization. The social perspective makes it possible, also from the theological perspective, to infer additional aspects of media education. Media education equips the stakeholders in the educational process with media and information competences, which are classified among the most significant human skills of the 21st century. This is because they enable participation in social, cultural and civic life, at the same time, preventing exclusion from the society, altered by continuous transformations in the ${ }^{26}$ media universe. As stressed by the authors of the Paris Declaration of 2014, critical thinking, creative and ethical use of media and information play a key role in contemporary social functioning. What is more, in this social optics, contemporary media classify as public good. Therefore, one of the dimensions of the principle of social justice is the right of access to media, information, education and knowledge in various socio-cultural contexts. Through media education, it is possible to participate

Łęcicki, „Edukacja medialna,” 78.

United Methodist Church, "Proper Use of Information."

Ptaszek, Edukacja medialna, 247-296.

See: Ananiadou - Claro, "21st Century Skills," 5-11. 
in activities undertaken for the common good. The role of media and information literacy (MIL) in intercultural and interreligious dialogue is also invaluable. Christians' engagement in evangelization activities supported by media education will result in an effective intercultural and interreligious dialogue, protection of citizens, especially in countries with low social capital and still fragile democratic culture. The above-mentioned activities can even be called a pre-evangelization stage ${ }^{27}$.

Mutual support of media education and new evangelization seems to be particularly important in promoting and defending the truth about God and the human being in the era of human communication hugely polluted by fake news. Pope Francis addressed this problem in 2018 in his media message, where we can read that: "What is at stake is our greed. Fake news often goes viral, spreading so fast that it is hard to stop, not because of the sense of sharing that inspires the social media, but because it appeals to the insatiable greed so easily aroused in human beings." ${ }^{28}$ And later in the same document, the Pope pinpoints that education is a process that can help face the challenge of fake news and their detrimental impact: "That is why education for truth means teaching people how to discern, evaluate and understand our deepest desires and inclinations, lest we lose sight of what is good and yield to every temptation." 29

In order to prudently and wisely create relations in the social space of the media, it is necessary to develop, first of all, competences of a communicative and ethical nature, to build a community and a communicative space for promoting the Gospel. The evangelization aspect of media education can help Christian leaders understand media culture and can help them develop skills of effective addressing contemporary evangelization audiences shaped by this culture. To do so effectively, the leaders must be equipped with skills of choosing the language means, strategies, methods and tools to match the perception capabilities and expectations of contemporary evangelization addressees ${ }^{30}$. Therefore, a claim seems justified that people with media skills and competences are highly likely to be effective in introducing into the sphere of virtual-real community the principles of social life based on Christian values.

\section{c. A New Competence: Media-Based Apologetics}

The third urge resulting from the analysis of contemporary media communications in the perspective of media education and in the context of the new evangelization is to introduce a new competence into the field of media literacy formation, which I would like to define here as media-based defence of faith (apologetics).

\footnotetext{
See: "Paris Declaration."

Pope Francis, WDSC 52.

Pope Francis, WDSC 52.

Iaquinto - Keeler, "Faith-Based," 22-23.
} 
Perceiving the media as a great gift from God and a work of human genius, the Catholic Church shows Her awareness of the fact that the media predominantly convey content that is fundamentally contrary to the Christian value system. These messages often stand in more or less direct opposition to the Gospel message. The media narrative is not neutral; selected values, ideas and worldviews stand behind it, served by large media corporations. In the post-synodal documents from the last three general synods, Pope Francis clearly notes that in addition to the positive side of media narratives, there is also a dark side, which represents anti-evangelization:

Indeed, "the digital environment is also one of loneliness, manipulation, exploitation and violence, even to the extreme case of the 'dark web'. Digital media can expose people to the risk of addiction, isolation and gradual loss of contact with concrete reality, blocking the development of authentic interpersonal relationships. [...] It should not be forgotten that "there are huge economic interests operating in the digital world, capable of exercising forms of control as subtle as they are invasive, creating mechanisms for the manipulation of consciences and of the democratic process (ChV, 88-89).

A contemporary participant in media communication, permanently inhabiting the media world, assimilates media constructions of reality. Media narratives are not only source of entertainment, but are a way of shaping and formatting our inner world, our values, attitudes and behaviours. An analysis of selected European Internet media content concerning Christians and Christianity shows that these messages replicate myths, perpetuate stereotypes and create new authority figures, who oppose the Church's doctrine and moral life. Not infrequent, either, are cases of deliberate provocation, profanity and even blasphemy in the spheres of sacralization for the Christians. One can even talk about cases of media sacralization of blasphemy (e.g. the case of the French satirical weekly Charlie Hebdo). One can go as far as to put forward a thesis that in contemporary culture, media narratives take on the qualities so far reserved only for the realm of the sacrum. This thesis is confirmed by the fact that the new culture created by the media industry is self-referential. The transgression of media towards the sacrum is becoming more and more visible.

The increasingly hostile behaviour recorded towards Christians in Europe's cultural circles also raises questions about the future relationship of the sphere of the sacred. The realm of European culture, which is being deprived of the sacred, distances itself from the message of the evangelical poverty and ceases to be educationally efficient, which ultimately leads to the loss of its own, European identity. This type of media activity fits into the current trend called by R. Guitton Christianophobia ${ }^{31}$, represented by the persecution of Christians in the world ${ }^{32}$.

Guitton, Cristianofobia.

32 See: Open Doors, World Watch List 2019. 
An American organization with a Catholic background, Center for Media Litera$c y$, suggests five key issues and questions in media education that equip each person with tools for deconstructing any media message. One of these questions relates to the content of the media text and asks what lifestyles, values and points of view are presented or omitted in the media text under analysis. This question is based on the fact that a key element making up the construction of the media message are values and viewpoints ${ }^{33}$. An ability to critically perceive and analyse media messages, based on the knowledge of the grammar of media language, giving the ability to read them, is essential to distinguish between truth and falsehood in media representations of reality.

Educating for a critical analysis of media narratives is the right way to go with contemporary teaching of the Church. Accepting this way allows for the awareness of the engineered gap between the Christian world and the major sector of contemporary culture. It seems to be the best way to prevent any kind of harm, especially in the realm of spiritual life and in particular the personalities of children and youth. However, all the above does not imply that media competences formed for apologetic purposes are to be predominantly defensive in nature. They are rather intended to equip a person with tools of critical and active extraction of the crumbs of truth, goodness and beauty from contemporary media culture and of participation in its creation ${ }^{34}$.

As noted by authors promoting media education based on the Christian faith, the above strategy indicates a need to build competence in three other areas ${ }^{35}$. Firstly, there is a need to know the Bible and Christian doctrine, passed on in a well-organized content and through didactically well-designed catechesis, as well as through the preaching and homiletic communications. Secondly, a need for an introduction to the understanding of contemporary media culture - as already discussed above. Thirdly, a need for developing an ability to critically approach Christian doctrine in its dialogue with contemporary culture. As emphasized by D. Steyn: "rationality and responsibility, rooted in an unshakeable faith in God, provide us a certain discernment and wisdom with which we can approach the options that the media poses." ${ }^{\prime 3}$

Concluding the observations made here, it should be stated that the new media competence necessary for contemporary evangelizers - the media-based apologetics - should not be understood in terms of a struggle against views contrary to Christianity; neither should it be conceived in terms of enclosing oneself within the limits of one's own line of argumentation, used for critical analysis of adversary media communications. Instead, media-based apologetics should strive to enter into these disputes and debates, accepting the rules of discourse they set, in order to under-

\footnotetext{
Center of Media Literacy, Literacy for the 21st Century, 9-26.

Iaquinto - Keeler, "Faith-Based Media," 21-22.

Iaquinto - Keeler, "Faith-Based Media," 22.

Steyn, "Screening the Screen."
} 
take, as H. Seweryniak puts it "an apologetics of dialogue" though "getting inside" those communication channels and transmissions ${ }^{37}$. This means being able to use language, grammar, communicative tools and strategies that match the nature of the media, so as to engage in a critical, creative and rational dialogue with them. It also means seeking points of contact and showing other dimensions of the problems under discussion from the point of view of knowledge, Christian doctrine and personal experience of the reality of faith. Only then may a space for evangelization emerge, which will lead to witness as the highest level of communication, both direct, interpersonal as well as mediated.

\section{Conclusions}

The analyses and arguments made in this article provide the basis for a positive verification of the thesis set out in the Introduction that media education is an essential tool to empower the effective new evangelization. As shown in the main part of the article, media education, defined in the reality of the Church in terms of media literacy formation, is deeply anchored in contemporary teaching of the Church. The outline of the selected components of the medial context of the new evangelization, even though incomplete and demanding further analysis, proves a need for introducing media literacy formation on a permanent basis in the various stages of forming the new evangelizers. The challenges pinpointed in the article, which emerge from the nature of the interrelation between media education and the new evangelization, highlight the Church's present-day and emergent tasks in terms of education, formation and evangelization. The problem of the interrelations between media education and evangelization, which has been taken up in the article, demands the formulation of pastoral postulates and educational proposals. According to the announcement contained in the Introduction, these postulates and proposals are subject to discussion in the second article, organically connected with the above presented content. As a way of concluding the deliberations in this part of my exposition - at the same time serving as an introduction to their continuation in the subsequent text - I have chosen words of Benedict XVI. In his last message on social media (2013), he points out the contemporary immersion of Christians in the world of digital media, whose tools can benefit the goals of the new evangelization. Nonetheless, as noted by the Pope, the salvific fruitfulness of the proclaimed Gospel does not ultimately result from the resources used, but "it is always because of the power of the word of God itself to touch hearts, prior to any of our own efforts." 38

37 Seweryniak, Apologia i dziennikarstwo, 19.

38 Benedict XVI, WDSC 47. 


\section{Bibliography}

Ananiadou, K. - Claro, M., "21st Century Skills and Competences for New Millennium Learners in OECD Countries," EDU Education Working Papers 41 (2009), http://www.oecdilibrary.org/docserver/download/218525261154.pdf?expires=1519292945\&id=id\&accname =guest\&checksum=1911848500E8B628AFBB8407ED683A9A [access: 24.01.2020].

Aparecida. V Ogólna Konferencja Episkopatów Ameryki Łacińskiej i Karaibów. Dokument końcowy. Jesteśmy uczniami i misjonarzami Jezusa Chrystusa, aby nasze narody miały w Nim życie, Polish edition (Gubin: Przystanek Jezusa 2014).

Beaton, R., "Between the Center and the Margins: Young Catholics, 'Sorta-Catholics' and Baptismal Identity," Sacramental Theology. Theory and Practice from Multiple Perspectives (ed. B.T. Morrill) (Basel: MDPI 2019) 69-84, https://www.mdpi.com/books/pdfview/ book/1804 [access: 01.03.2020].

Benedict XVI, Encyclical Letter Caritas in veritate (2009) (=CV).

Benedict XVI, Message of the Holy Father Benedict XVI for the 43rd World Communications Day New Technologies, New Relationships. Promoting a Culture of Respect, Dialogue and Friendship, http://www.vatican.va/content/benedict-xvi/en/messages/communications/ documents/hf_ben-xvi_mes_20090124_43rd-world-communications-day.html [access: 20.02.2020] (= WDSC 43).

Benedict XVI, Message of His Holiness Pope Benedict XVI for the 44th World Communications Day The Priest and Pastoral Ministry in a Digital World: New Media at the Service of the Word, http://www.vatican.va/content/benedict-xvi/en/messages/communications/ documents/hf_ben-xvi_mes_20100124_44th-world-communications-day.html [access: 20.02.2020] (=WDSC 44).

Benedict XVI, Message of His Holiness Pope Benedict XVI for the 47th World Communications Day Social Networks: portals of truth and faith; new spaces for evangelization, http://www. vatican.va/content/benedict-xvi/en/messages/communications/documents/hf_ben-xvi_ mes_20130124_47th-world-communications-day.html [access: 20.02.2020] (=WDSC 47).

Celli, C.M., "Ewangelizacja i nowe techniki komunikacji". An Inauguration Lecture at WSKSiM, Toruń, 28.10.2013, http://www.radiomaryja.pl/multimedia/inauguracja-roku-akademickiego-wsksim-wyklad-inauguracyjny-ks-abp-claudio-marii-celli/ [access: 29.11.2019].

Center of Media Literacy, Literacy for the 21st Century. An Overview \& Orientation Guide to Media Literacy Education (no place of publication: 2005).

Chmielewski, M., "Edukacja medialna - rola w Kościele i kierunki rozwoju," Biuletyn Edukacji Medialnej 1 (2019) 11-30.

Chmielewski, M., "Kultura medialna jako wyzwanie dla komunikacji wiary w świetle orędzi Benedykta XVI na Światowe Dni Środków Społecznego Przekazu," Biuletyn Edukacji Medialnej 1 (2016) 156-178.

Chmielewski, M., "Youcat - wskazania dla katechezy w kulturze medialnej," Catechetica porta fidei (eds. A. Kiciński - P. Goliszek) (Lublin: Natan 2012) 193-216.

Droga formacji prezbiterów $w$ Polsce. Ratio institutionis sacerdotalis pro Polonia. Projekt (no place of publication: 2019) (manuscript).

Drzewiecki, P., Edukacja medialna a nauczanie religii w szkole (Warszawa: Elipsa 2013). 


\section{MIROSŁAW CHMIELEWSKI}

Fedorov, A., Media and Information Literacy Education Dictionary (Moscow: ICO 2017), https://www.researchgate.net/publication/311675000_Media_and_Information_Literacy_Education_Dictionary [access: 27.01.2020].

Francis, Apostolic Exhortation Evangelii gaudium (2013) (=EG).

Francis, Encyclical Letter Lumen fidei (2013) (= LF).

Francis, Message of Pope Francis for the 48th World Communications Day Communication at the Service of an Authentic Culture of Encounter, http://w2.vatican.va/content/francesco/ en/messages/communications/documents/papa-francesco_20140124_messaggio-comunicazioni-sociali.html [access: 04.03.2019] (= WDSC 48).

Francis, Message of His Holiness Pope Francis for World Communications Day, 24 January 2018 "The Truth will Set You Free" (Jn 8:32). Fake News and Journalism for Peace, http://w2. vatican.va/content/francesco/en/messages/communications/documents/papa-francesco_20180124_messaggio-comunicazioni-sociali.html [access: 20.02.2020] (=WDSC 52).

Francis, Apostolic Exhortation Christus vivit (2019) (=ChV).

General Secretariat of the Synod of Bishops, The World of New Generations According to the Online Questionnaire (Rome: Libreria Editrice Vaticana 2018), http://www.synod2018.va/ content/dam/synod2018/documenti/Libri/libro\%20mondo\%20delle\%20nuove\%20generazioni.pdf [access: 26.02 .2020 ].

General Secretariat of the Synod of Bishops, Final Document of the Synod of Bishops on Young People, Faith and Vocational Discernment, http://www.synod.va/content/synod2018/en/ fede-discernimento-vocazione/final-document-of-the-synod-of-bishops-on-young-people--faith-an.html [access: 26.02.2020].

Guitton, R., Cristianofobia. La nuova persecuzione (Torino: Lindau 2010).

Iaquinto, S. - Keeler, J., "Faith-Based Media Literacy Education: A Look at the Past with an Eye toward the Future," Journal of Media Literacy Education 4/1 (2012) 12-31.

John Paul II, Encyclical Letter Redemptoris missio (1990) (= RM).

Kasowski, R., Edukacja medialna w Wyżsych Seminariach Duchownych w Polsce po roku 1992 (Diss.; Warszawa: UKSW 2018).

Kawecki, W., "Wizualność kultury i teologii," Kultura wizualna - teologia wizualna (eds. W. Kawecki, - J.S. Wojciechowski, - D. Żukowska-Gardzińska) (Warszawa: Instytut Jana Pawła II 2011) 15-33.

Kawecki, W., Kościół i kultura w dialogu (Kraków: Homo Dei 2008).

Kiciński, A., "Dialog Mistrza z uczniami. Kompendium Katechizmu Kościoła Katolickiego," Katecheta 49/10 (2005) 16-22.

Kompendium Katechizmu Kościoła Katolickiego (Watykan: Libreria Editrice Vaticana 2005).

Łęcicki, G., "Edukacja medialna jako istotna cecha nowoczesnego społeczeństwa," Kultura-Media-Teologia 3 (2010) 70-80.

Open Doors, World Watch List 2019, https://www.opendoorsusa.org/wp-content/uploads/2019/01/WWL2019_FullBooklet.pdf [access: 01.03.2020].

„Paris Declaration on Media and Information Literacy in the Digital Era," http://www.unesco.org/ new/fileadmin/MULTIMEDIA/HQ/CI/CI/pdf/news/paris_mil_declaration.pdf [access: 15.02.2020].

Ptaszek, G., Edukacja medialna 3.0. Krytyczne rozumienie mediów cyfrowych $w$ dobie Big Data i algorytmizacji (Kraków: Wydawnictwo Uniwersytetu Jagiellońskiego 2019). 
Seweryniak, H., Apologia i dziennikarstwo (Warszawa: Wydawnictwo Naukowe UKSW: 2018). Steyn, D., „Screening the Screen: Media literacy and the Christian,” Dialogue (2006), http://circle. adventist.org/files/CD2008/CD2/dialogue/articles/17_3_steyn_e.htm [access: 01.03.2020].

Szajda, A., Kompetencje medialne nauczycieli religii archidiecezji lubelskiej w świetle dokumentów Kościoła i badań własnych. Studium z edukacji medialnej (Diss.; Lublin: KUL 2018).

Szczepaniak, M., "Patrzenie obrazu. Obrazowanie jako strategia komunikacyjna w przepowiadaniu," Teologia Praktyczna 16 (2015) 111-122.

Thoman, E., "I Hate It, but I Love It: Television and Listerine: A Teacher Turned Communicator Explores the Challenges of Media Education in the Catholic Church," Media\&Values 1 (1977) 4-6.

United Methodist Church, "Proper Use of Information Communication Technologies”, (2004), http://archives.umc.org/interior_print.asp?ptid=4\&mid=6813 [access: 28.02 .2020 ].

Wielebski, T., "Istota i sposoby realizacji nowej ewangelizacji," Studia Aloisiana 5/3 (2014) 61-82.

Youcat. Katechizm Kościoła Katolickiego dla młodych (Częstochowa: Edycja Świętego Pawła 2011). 
